\title{
Strategies of Sustainable Cooperative Partnerships
}

\author{
Misbahul Munir ${ }^{1}$, Maretha Ika Prajawati ${ }^{1} \&$ Basir S. $^{2}$ \\ ${ }^{1}$ Management Faculty, Maulana Malik Ibrahim State Islamic University, Malang, Indonesia \\ ${ }^{2}$ School of Strategic and Global Studies, University of Indonesia, Jakarta, Indonesia \\ Correspondence: Maretha Ika Prajawati, Management Faculty, Maulana Malik Ibrahim State Islamic University, \\ Malang, Indonesia. E-mail: maretha@uin-malang.ac.id
}

Received: August 28, 2020

Accepted: October 13, 2020

Online Published: January 20, 2021

doi:10.5430/ijfr.v12n3p157

URL: https://doi.org/10.5430/ijfr.v12n3p157

\begin{abstract}
Cooperatives also have an active role in efforts to enhance the life of the nation and to realize a national economy based on the principles of family and economic democracy. The problem faced by cooperatives today is that cooperatives are less able to become business institutions that provide good services to all members and society in general. Limited funds and low human resources become a barrier for cooperatives to develop. Partnerships between cooperatives and other financial institutions are alternatives to improve cooperatives in developing their businesses. This study purpose on developing a cooperative economic development through a strategic partnership approach between cooperatives and other financial institutions so that cooperatives can grow, develop, and be sustainable. The method used in this research is descriptive qualitative research using in depth interview with informant. The informant is a cooperative for savings and loan managers who are willing to be interviewed in Batu City. The results showed that the cooperative strategy in building partnerships between cooperatives and other financial institutions was carried out based on the principle of mutual benefit. Cooperatives need to improve themselves so that they can meet the feasible and bankable criteria. Thus partnerships between cooperatives and other financial institutions will be established, thus cooperatives will grow and develop.
\end{abstract}

Keywords: partnership, cooperative, sustainable

\section{Introduction}

Cooperatives have the potential to increase community income in the micro-scale informal economy sector (Djawahir, 2012). Cooperatives have an active role in enhancing the life of the nation and creating a national economy based on the principles of family and economic democracy. Furlough and Strikwerda (1999 cited in Hill, 2000) suggested that cooperatives have an important role in contributing to the economic development of both capitalist and non-capitalist countries. For cooperatives, the welfare of members and the community through business maximization is the goal to be achieved.

The nature of cooperatives is basically as a value system. The cooperative does not only want to display its different forms from other forms of the company, they also want to uphold a certain set of values in the economic field (Baswir, 2003). Wijono (2005) states that, despite the development of microfinance institutions, including savings and loan cooperatives, there are still many obstacles in accessing sources of financing from formal financial institutions. The requirements for proposing financing include the adequacy of guarantees, capital, and business feasibility (bankable).

Almost all cooperatives currently need financial assistance to develop their businesses. The inability of cooperatives to absorb funds from banks is a very classic problem, but also very crucial for the development of cooperatives themselves. This is closely related to the cooperative management capabilities that exist, including the low ability of human resources owned, mastery of technology, licensing, and ability to access markets. Another factor is the cooperative's lack of understanding of the systems and procedures for obtaining assistance from banks and the lack of collateral in obtaining assistance from financial institutions.

A study of partnerships between cooperatives and financial institutions has been carried out by Al-Muharrami and Hardy (2013) while Rabobank (2012) reported on partnerships between Rabobank and cooperatives in 14 countries in the world. Partnerships are carried out in the form of capitalization, coaching, and assistance in improving cooperative efforts. Deepak (2007) conducted a study on the reform of the banking sector and credit cooperative 
institutions in Maharashtra, while Gupta and Suman (2012) conducted studies on cooperative banks with specific reference to lending practices and Jessop et al. (2012) found that cooperatives can be very effective partners for banks and microfinance institutions to extend credit to farmers.

Panggabean (2014) findings indicate banking cooperation, cooperatives, and MFIs as supporting the empowerment of MSMEs. The patterns of cooperation developed by banks, cooperatives, and other MFIs are the pattern of executing and channeling. Credit services to MSMEs are carried out individually and follow each legal umbrella. Coordination between credit service actors in the empowerment of MSMEs has not yet been created. The pattern of cooperation between cooperatives and banks is still in terms of executing and channeling, namely in the form of cooperation in savings and loan funding. The already established collaboration needs to be increased again so that a better climate of cooperative empowerment can be created.

Previous studies have revealed obstacles and problems encountered in cooperation between cooperatives and financial institutions using conventional banks. Cooperative cooperation through banking institutions has not been able to provide maximum benefits for cooperatives. The condition of human resources in cooperatives and the lack of a maximum pattern of cooperation between cooperatives and financial institutions provide an opportunity for a review of the development of sharia-based cooperative economic development models. Therefore, it is expected that a cooperative economic development model can be obtained that can benefit all parties.

\section{Literature Review}

\subsection{Cooperative Development Strategy}

The practical objective of the strategy is to provide a plan that uses inputs, choices, and outputs to achieve the goals and objectives and policies of the organization (Davies, 2000). Sustainable competitive advantage depends on choosing the right strategy that is consistent with the competing resources and capabilities of the organization and industry in which they are located (Mostardeiro, 2007). Strategy as an effort to create a valuable and unique position, including the difference in activities, is also expressed in work done to achieve goals through a careful process (Porter, 1996). Strategic innovation as a key to wealth creation entails the capacity to rethink existing industrial models in ways that create new value for customers, competitors who misstep, and produce new creations from shareholder wealth (Hamel, 1998). Based on the opinions expressed by Porter (1996), Hamel (1998) and Mostardeiro (2007), it means that the right strategy for the organization can create valuable positions and generate wealth for the organization.

\subsection{Excellence Concept of Partnership}

Looking at the concept of partnership that has been discussed, the benefits of partnership, as in co-operation (cooperation), lie in trust. Trust as a whole in human life is a strategic aspect in building the success of individuals/people, society, and organizations. Lazar (2000) conducted a literature study on trust in partnerships and concluded that trust can grow over time as a result of achieving sustainable partnerships.

What needs to be observed in building partnerships is how to build trust. Building trust means building culture, which is not just building customs, traditions, and habits, but building abilities (knowledge), skills (skills), and attitudes, where the three things are manifested in the form of creativity, taste, and intention. Therefore, if the superiority of a partnership lies in trust, this is a cultural advantage, meaning the superiority of creativity, taste, and intention. Modern civilization views cultural superiority as very much rooted in honesty, justice and policy so that it becomes a triangulation for trust. Therein lies the partnership advantage.

\section{Method}

Bagian metode penelitian dapat diperjelas dengan menjelaskan langkah-langkah operasional dan tindakan penelitian secara jelas. Langkah analisis data perlu dijelaskan.

This study is a qualitative study using a phenomenological approach. Conducted in Malang, the Observation Unit in this study was called an informant and included individual cooperative business actors. Criteria for informants in this study are the informants are cooperative management who have had at least three years of experience in the field of cooperatives and/or have served as an important function in the management of cooperatives during the last two years. Determination of the number of informants in this study was carried out using criteria of the degree of saturation of the information obtained. Based on the results of interviews with seven informants, information obtained from the eighth informant has similarities with information from the seven previous informants, so the authors consider it sufficient to use just seven informants. 


\section{Results and Discussion}

\section{Strategies for Cooperative / UMKM Development Through Partnerships between Cooperatives and Other Financial Institutions}

The partnership must be seen as a strategy that can empower cooperatives to be independent and gain the trust of the parties concerned. The empowerment process can be carried out for cooperatives by providing training, assistance, and counseling in a programmed manner until the cooperative can manage the business independently and is carried out based on good and profitable business governance principles.

The formulation of the concept of empowerment in the context of cooperative empowerment strategies in this study is more directed at the formation of empowerment models that are locally based. The empowerment model involves all stakeholders as empowerment actors, by playing their respective roles, especially in efforts to change the ability of the actors in solving problems faced in the business, such as access to capital. Empowerment has three dimensions: popular competence, social-political ability, and participatory competence (Christens et al, 2015).

Based on some previous concepts regarding development or empowerment, it can be understood that, to empower cooperatives, financial institutions, with the support of government policies, must develop the cooperative environment in Malang Regency. Financial institutions must have a partiality to cooperatives and not be rigid in applying their provisions to build economic power (empowering) through capacity building. Through training and technical guidance in carrying out cooperative activities, cooperatives can become feasible in partnership, which means the efforts of financial institutions, with the support of local governments, can prepare cooperatives as equal partners in developing the economy. Moreover, financial institutions can also develop through protection. That is, financial institutions must make efforts to protect their partners so that their activities can develop rapidly.

Interpreting the results of the informants of the cooperative manager, in general, are not bankable, although it is feasible to be a phenomenon. Financial institutions base being bankable on asset guarantees, not on business guarantees carried out by cooperatives, so that it becomes a complicated problem for financial institutions and cooperatives. The phenomenon of not being bankable is not a serious problem if it can be understood and simplified by financial institutions so that cooperatives may easily enter into partnerships. The financial institution must change the paradigm from understanding bankability to become feasible because the principle of excessive prudence can harm the development of the financial institution itself.

Existing financial institutions can build a new paradigm in partnering with cooperatives. Financial institutions should apply the model of cooperation and profit-sharing so that partnership with the cooperative is a sufficiently feasible assessment. Financial institutions must be involved in cooperative activities, assisting cooperatives starting from the production process to product marketing. Financial institutions are not only limited to lending partners, but are also willing to assist in the production and find markets for partner products. Cooperative / UMKM Economic Development Model Through Partnerships between Cooperatives and Other
Financial Institutions

A limited guarantee is an urgent problem for which a solution must be found if the local government is to develop. A cooperative is a forum that is very suitable for the community in building the community's economy because, in general, the community is not familiar with using bank services. Society in general has a low level of education, so dealing with banking is too difficult for them. The solution is to use cooperatives. However, if the savings and loan cooperative is powerless, then how can that right be realized? To realize community empowerment, first empower cooperatives. The financial institution must change the paradigm in partnering with cooperatives by providing convenience without requiring collateral, so that it can assess collateral in the form of a business carried out by cooperatives. Two important things are maintained by cooperatives, namely how to create the quality of human resource managers and the quality of human resources of cooperative members, namely:

The competency ability of cooperative managers must be improved so that it becomes the ability of cooperatives to provide guarantees to financial institutions.

Also, honesty needs to be maintained continuously so that financial institutions trust and are willing to partner, because partnerships can be built on trust between cooperatives and financial institutions.

The findings of Daniela (2012) show a similarity with the results of this study, in that one of the obstacles is the limited collateral owned by cooperatives to obtain credit from banks, in addition to which administrative records are not fully owned by cooperatives, so cooperatives have difficulty meeting the specified requirements by banks and other financial institutions. 
The cooperative strategy in building partnerships with financial institutions can be done by promoting the principle of benefits, namely mutual respect and mutual benefit. This will encourage financial institutions, including banks, to be motivated to provide guidance and assistance to cooperatives. On the other hand, cooperative businesses need to receive guidance and assistance by financial institutions so that they can meet the feasible and bankable criteria. These are important components that must be met, so that cooperation can occur in the form of partnerships between cooperatives and other financial institutions. If the partnership can run well, the cooperatives will grow and develop. The partnership is a mutually beneficial activity with various forms of cooperation in dealing with and strengthening one another. The main objective of the partnership is to develop independent and sustainable development with a foundation and structure of a strong and fair economy with the people's economy as its main backbone.

\section{Conclusion and Future Research}

The cooperative strategy in building partnerships between cooperatives and other financial institutions is based on the principle of mutual benefit. Cooperatives need to improve themselves so that they can meet the feasible and bankable criteria. Thus a partnership between cooperatives and other financial institutions will be established, which, in turn, cooperatives will grow and develop.

For further research, other researchers can examine more specifically the strategies that must be carried out by cooperatives in facing competition with other financial institutions, so that cooperatives can survive and develop as economic pillars and their benefits can be felt directly by various groups of society.

\section{References}

Al-Muharrami, S., \& Hardy, D. C. (2014, November). Cooperatives and Islamic Banks: What Can They Learn From Each Other?. IMF Working Papers 12(184), 73-94. https://doi.org/10.5089/9781484380833.001

Baswir, R. (2003). Dinamika Korupsi di Indonesia: Dalam Perspektif Struktural. Jurnal Universitas Paramadina, 2(3), 247-263.

Christens, B. D., Winn, L. T., \& Duke, A. M. (2015). Empowerment and Critical Consciousness: A Conceptual Fertilization. Adolescent Reseacrh Review 1, 15-27. https://doi.org/10.1007/s40894-015-0019-3

Daniela R S. (2012). Bank Loans and Small Firm Financing in Romania. Annales Universitatis Apulensis Series Oeconomica, 14(1), 2012. https://doi.org/10.29302/oeconomica.2012.14.1.15

Davies, W. (2000). Understanding strategy. Strategy \& Leadership, 28(5), 25-30. https://doi.org/10.1108/10878570010379428

Deepak, S. (2007, July-December). Banking Sector Reforms and Co-operative Credit Institutions in Maharashtra: A Synthesis. Agricultural Economics Research Review, 235-254.

Djawahir, A H. (2012). Perkoperasian: Materi Pandampingan Koperasi Wanita. Makalah. Pusat Pengkajian dan Pengembangan UMKM, Koperasi, dan Kewirausahaan Masyarakat Fakultas Ekonomi dan Bisnis Universitas Brawijaya. Malang. Tidak dipublikasikan.

Gupta, J., \& Suman, J. (2012). A study on Cooperative Banks in India with special reference to Lending Practices. International Journal of Scientific and Research Publications, 2(10), 1-6. https://doi.org/10.15373/22778179/OCT2013/123

Hamel, G. (1998). Strategy innovation and the quest for value. Sloan Management Review, Winter, 7-14.

Hamel, G., \& Prahalad, C. K. (1989). Strategic Intent. Harvard Business Rewiew, 67(3).

Hamel, G., \& Prahalad, C. K. (1994). Competing for the Future. Harvard Business School Press.

Hill, R. (2000). The Case of Missing Organizations: Co-operatives and the Textbooks. Journal of Economic Education, 31(3), 281-295. https://doi.org/10.1080/00220480009596786

Jessop, R., Diallo, B., Duursma, M., Mallek, A., \& Harms, J. van Manen. (2012). Creating Access to Agricultural Finance: Based on a horizontal study of Cambodia, Mali, Senegal, Tanzania, Thailand and Tunisia. Imprimerie de Montligeon. Agence Française de Développement.

Lazar, F. D. (2000). Project partnering: improving the likelihood of win/win outcomes. Journal of Management in Engineering, 16(2), 71-83. https://doi.org/10.1061/(ASCE)0742-597X(2000)16:2(71)

Mostardeiro, M. (2007). CSR Strategy Formation Processes: A Multiple Case Study from Brazil. Social Responsibility Journal, 3(1), 59-67. https://doi.org/10.1108/17471117200700007 
Panggaben, R. (2014). Kerjasama Bank, Koperasi, dan Lembaga Keuangan Mikro (LKM) Mendukung Pemberdayaan Usaha Mikro Kecil dan Menengah (UMKM). Diakses 14 Desember 2014. Retrieved from http://www.smecda.com/deputi7/file_Infokop/VOL15_02/4_\%20riana.pdf

Porter, M. E. (1996, November- December). What is strategy?. Harvard Business Review, 61-79.

Rabobank. (2012). Cooperatives and Rural Financial Development: Great Opportunities and Surmountable Difficulties' is a product of the Directorate Cooperative and Sustainable Business, Rabo Development, and Rabobank Foundation. Retrievced from https://www.rabobank.com/en/images/Cooperative-and-Rural-Financial- Development.pdf

Wijono, W. W. (2005). Pemberdayaan Lembaga Keuangan Mikro sebagai salah satu pilar system keuangan nasional - Upaya konkrit memutus mata rantai kemiskinan. Kajian Ekonomi dan Keuangan edisi Khusus, Indonesia.

\section{Copyrights}

Copyright for this article is retained by the author(s), with first publication rights granted to the journal.

This is an open-access article distributed under the terms and conditions of the Creative Commons Attribution license (http://creativecommons.org/licenses/by/4.0/). 